\title{
Causes of legume-rotation effects in increasing cereal yields across the Sudanian, Sahelian and Guinean zone of West Africa
}

\author{
A. Bürkert ${ }^{1)}$, M. Bagayoko ${ }^{2)}$, S. Alvey ${ }^{3)}$ and A. Bationo ${ }^{4)}$ \\ I) Institute of Crop Science, University of Kassel, Steinstr. 19, D-37213 Witzenhausen, Germany, buerkert@wiz.uni- \\ kassel.de \\ 2) Institut d'Economie Rurale (IER),B.P.258,Bamako,Mali, Minamba.Bagayoko@ier.ml \\ 3) Department of Environmental Sciences, University of California Riverside, Riverside, CA 92521, USA, \\ smalv@mail.ucr.edu \\ 4) TSBF-UNESCO, United Nations Complex, Gigiri, P.O. Box 30592, Nairobi, Kenya, a.bationo@cgiar.org
}

Key words: acid phosphatase, mineral nitrogen, mycorrhizae, nematodes, $\mathrm{pH}$, phosphorus mobilisation, rhizosphere

\begin{abstract}
On-farm experiments and pot trials were conducted on eight West African soils to explore the mechanisms governing the often reported legume rotation-induced cereal growth increases in this region. Crops comprised pearl millet (Pennisetum glaucum L.), sorghum (Sorghum bicolor Moench), maize (Zea mays L.), cowpea (Vigna unguiculata Walp.) and groundnut (Arachis hypogaea L.). In groundnut trials the observed 26 to $85 \%$ increases in total dry matter (TDM) of rotation cereals (RC) compared with continuous cereals (CC) in the $4^{\text {th }}$ year appeared to be triggered by site- and crop-specific early season differences in nematode infestation (up to 6-fold lower in RC than in $\mathrm{CC}$ ), enhanced Nmin and a 7\% increase in mycorrhizal (AM) infection. In cowpea trials yield effects on millet and differences in nematode numbers, $\mathrm{N}_{\min }$ and $A M$ were much smaller. Rhizosphere studies indicated effects on $\mathrm{pH}$ and acid phosphatase activity as secondary causes for the observed growth differences between RC and CC. In the study region legume-rotation effects on cereals seemed to depend on the capability of the legume to suppress nematodes and to enhance early $\mathrm{N}$ and $\mathrm{P}$ availability for the subsequent cereal.
\end{abstract}

\section{Introduction}

Legume rotations have been advocated as a low input strategy to increase cereal yields on acid sandy soils of sub-Saharan West Africa that are notoriously low in phosphorus $(\mathrm{P})$ and nitrogen $(\mathrm{N})$. However, this view is based on a very limited number of comparative yield trials providing site-specific results (Bationo et al., 1998; Nicou, 1978; Stoop and van Stavern, 1981). To critically assess the merits of legume rotations for different soils and crops of the region, information is needed about the mechanisms governing cereal yield increases.

\section{Materials and methods}

Field experiments with pearl millet, sorghum, maize, cowpea and groundnut were conducted from 1995 to 1999 under rainfed conditions at eight sites in Niger, Burkina Faso and Togo (Bagayoko et al., 2000b). The sites provided a gradient of annual rainfall from 510 to 1300 $\mathrm{mm}$ with a corresponding range in topsoil $(0-0.2 \mathrm{~m}) \mathrm{pH}$ from 4.1 to 5.6 , in cation exchange capacity (CEC) from 0.8 to $3.3 \mathrm{cmol}_{\mathrm{c}} \mathrm{kg}^{-1}$, in mineral $\mathrm{N}$ (Nmin) from 5 to $18 \mathrm{mg}$ $\mathrm{kg}^{-1}$, in organic carbon from 1.5 to $6.5 \mathrm{~g} \mathrm{~kg}^{-1}$ and in clay content from 20 to $160 \mathrm{~g} \mathrm{~kg}^{-1}$. The field experiments were used to record data of crop yields, root infection with arbuscular mycorrhizae (AM) and nematode infestation. Additionally, pot and root box experiments with $\mathrm{CC}$ and RC soil from two of the sites (Fada and Gaya) were set up to investigate soil-root interactions under controlled conditions.

\section{Results and discussion}

Legume-induced increases in cereal total dry matter (TDM) as recorded in the field experiments were site- and crop-specific, relatively consistent over years, but tended to grow over time. In the $4^{\text {th }}$ trial year groundnut rotations led to average TDM increases in RC between 26 and $85 \%$ compared with CC. Respective increases in cowpea systems varied between -3 and $26 \%$ (Table 1 ).

Early season $\mathrm{N}_{\text {min }}$ levels in RC of cowpea sites tended to be higher than in $\mathrm{CC}$ but such differences with up to $114 \%$ at Fada (Bagayoko et al., 2000b) and $89 \%$ at Koukombo (Alvey at al., unpublished) were only significant at groundnut sites. AM infection of millet roots was significantly higher in RC than in CC (Table 2) but differences declined over the growing season. The same was found for sorghum (data not shown). Regardless of the amount of applied $\mathrm{P}$ in the multi-factorial field experiment, nematode numbers were up to six-times lower in RC than in $\mathrm{CC}$ at Fada but no rotation effects on nematode infestation were noted at Gaya (Figure 1).

Under controlled conditions legume-rotation effects on cereal growth were even larger than in the field and similar effects on nematodes and AM infection were found (data not shown). Bagayoko et al. (2000a) reported from the field trials at Goberi that the $\mathrm{pH}$ at the rhizoplane of millet was 1.9 units higher than in the bulk soil at 45 days after sowing (DAS) and 1.2 units at 75 DAS. Respective differences were 0.6 units at 50 DAS and 0.4 units at 80 DAS at Gaya. At all sites, $\mathrm{pH}$ levels followed the pattern rhizoplane $>$ rhizosphere $>$ bulk soil. For sorghum at Kouaré, $\mathrm{pH}$ increases at the rhizoplane reached a maximum of 0.3 
units, much smaller than in millet, and were not statistically significant (data not shown). Rotation-induced $\mathrm{pH}$ increases in the respective bulk soils were noted under controlled conditions at Fada (Figure 2) and to a lesser degree also at Koukombo and Kaboli (data not shown). These differences are still poorly understood, as are those in the rhizosphere, and may be due to particular properties of decomposing groundnut crop residues (Yan and Schubert, 2000).

Table 1. Legume-rotation effects on cereal total dry matter (TDM) in sub-Saharan West Africa. Data are means across $\mathrm{P}$ and $\mathrm{N}$ levels after three cropping cycles.

\begin{tabular}{|c|c|c|c|}
\hline Site & $\begin{array}{l}\text { Rain } \\
{\text { mm } \mathrm{yr}^{-1}}^{-1}\end{array}$ & System & $\begin{array}{l}\text { TDM } \\
\mathrm{kg} \mathrm{ha}^{-1}\end{array}$ \\
\hline \multirow[t]{2}{*}{ Bani } & \multirow[t]{2}{*}{510} & Continuous millet & 3080 \\
\hline & & Millet after cowpea & $3420 * *$ \\
\hline \multirow[t]{2}{*}{ Sadoré } & \multirow[t]{2}{*}{560} & Continuous millet & 3500 \\
\hline & & Millet after cowpea & $4310 * * *$ \\
\hline \multirow[t]{2}{*}{ Kara } & \multirow[t]{2}{*}{590} & Continuous millet & 4430 \\
\hline & & Millet after cowpea & $5580 * * *$ \\
\hline \multirow[t]{2}{*}{ Goberi } & \multirow[t]{2}{*}{600} & Continuous millet & 4220 \\
\hline & & Millet after cowpea & $4800 * * *$ \\
\hline \multirow[t]{2}{*}{ Gaya } & \multirow[t]{2}{*}{800} & Continuous millet & 2600 \\
\hline & & Millet after cowpea & $2510 \mathrm{~ns}$ \\
\hline \multirow[t]{2}{*}{ Fada } & \multirow[t]{2}{*}{850} & Continuous sorghum & 2680 \\
\hline & & Sorghum after cowpea & $3630 * * *$ \\
\hline \multirow[t]{2}{*}{ Kouk. } & \multirow[t]{2}{*}{1100} & Continuous maize & 4990 \\
\hline & & Maize after groundnut & $6280 * * *$ \\
\hline \multirow[t]{2}{*}{ Kaboli } & \multirow[t]{2}{*}{1300} & Continuous maize & 3440 \\
\hline & & Maize after groundnut & $6350 * * *$ \\
\hline
\end{tabular}

**, *** significant at $\mathrm{P}<0.01$ and $\mathrm{P}<0.001 ; \mathrm{ns}=$ not significant

Table 2. Root infection by mycorrhizae (AM) in millet (0-0.3m soil depth) as affected by cropping systems in a field experiment at Sadoré, Goberi and Gaya in 1997.

\begin{tabular}{llll}
\hline Cropping system & Sadoré & Goberi & Gaya \\
& $35 \mathrm{DAS}^{a}$ & 45 DAS & 50 DAS \\
& $\mathrm{AM} \mathrm{infection} \mathrm{( \%} \mathrm{of} \mathrm{roots} \mathrm{)}^{\mathrm{b}}$ & \\
\hline Continuous millet & $23 \mathrm{a}^{\mathrm{b}}$ & $27 \mathrm{a}$ & $11 \mathrm{a}$ \\
Millet after cowpea & $32 \mathrm{~b}$ & $48 \mathrm{~b}$ & $31 \mathrm{~b}$ \\
\hline
\end{tabular}

${ }^{a}$ days after sowing; ${ }^{b}$ significantly different at $\mathrm{P}<0.001$

Acid phosphatase activity at the root surface of sorghum was lower in rotation soil indicating improved $\mathrm{P}$ nutrition of seedlings and a subsequently smaller exudation of phosphatase from the root. In the rhizosphere, of rotation sorghum, however, an up to $74 \%$ higher phosphatase activity was noted (Figure 2). This was most likely the consequence of microorganisms that may have substantially contributed to the consistent increase of the measured $\mathrm{P}$ fractions in rotation soil compared with continuous soil (Alvey et al., 2001).

The combination of (i) improved $\mathrm{P}$ availability through changes in soil $\mathrm{pH}$, earlier AM infection, increased rhizosphere phosphatase activity and decreased parasitic nematode populations and (ii) higher levels of early season $\mathrm{N}_{\text {min }}$ likely explain the observed growth differences between RC and CC on the acid nutrient poor soils of subSaharan West Africa. Site-specific differences of such rotation effects likely depend on the legume component used (groundnut effects $>$ cowpea effects), the ability of the cereal crop to cope with low nutrient availability (millet $>$ sorghum $>$ maize) and nematode infestation levels.

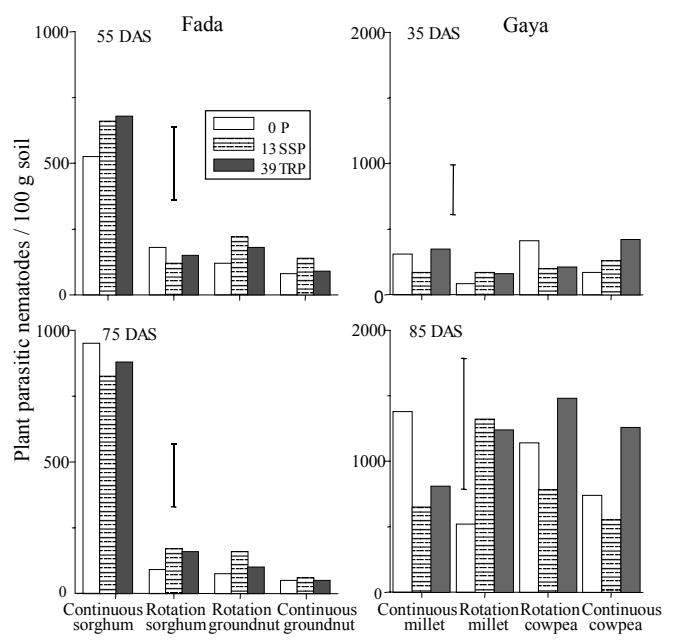

Figure 1. Effects of cropping system on nematodes without $\mathrm{P}$, with annually $13 \mathrm{~kg} \mathrm{P}^{-1} \mathrm{SSP}$ and with $39 \mathrm{~kg}$ $\mathrm{P}$ once as Tahoua rockphosphate (TRP) at Fada and Gaya in 1998
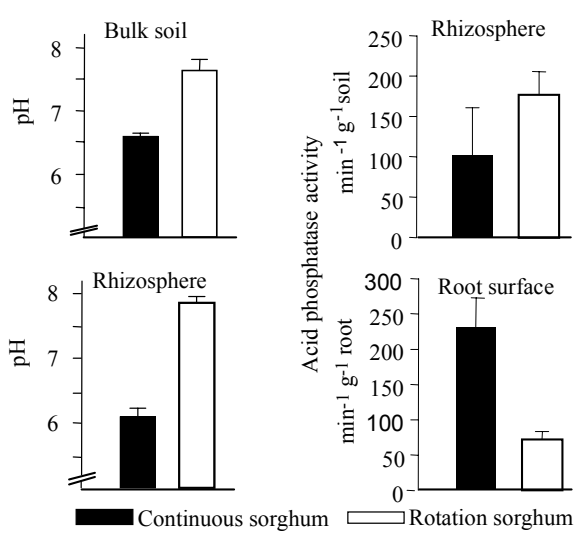

Figure 2. Effects of cropping system on $\mathrm{pH}$ and on acid phosphatase activity at the root of sorghum at Fada 37 days after sowing (after Alvey et al., 2001).

\section{References}

Alvey S, Bagayoko M, Neumann G and Buerkert A 2001 Plant Soil (in press).

Bagayoko M, Alvey S, Buerkert A and Neumann G 2000a Plant Soil 225, 117-127.

Bagayoko M, Buerkert A, Lung G, Bationo A and Römheld V 2000b Plant Soil 218, 103-116.

Bationo A, Lompo F and Koala S 1998 Agric. Ecosyst. Environ. 71, 19-35.

Nicou R 1978 Agron. Trop. 33, 51-61.

Stoop WA and van Stavern JP 1981 In Biological Nitrogen Fixation Technology for Tropical Agriculture. Eds. PC Graham and SC Harris. pp. 653-657. CIAT, Cali, Colombia. 